\title{
Phylogenetic Analysis of Bacterial Populations Found in Groundwater and an Acidic Stream Draining from an Abandoned Coal Mine
}

\author{
IN-GI KIM ${ }^{1}$, YASUHIRO KASAHARA ${ }^{2}$ and KYUNG-SOOK WHANG ${ }^{1 *}$ \\ ${ }^{1}$ Department of Microbiology, Mokwon University, Doan-Dong 800, Seo-Ku, Daejon 302-729, Korea \\ ${ }^{2}$ Graduate School of Biological Science, Nara Institute of Science and Technology, Takayama 8916-5, Ikoma, \\ 630-0101, Japan
}

(Received February 18, 2001-Accepted July 5, 2001)

\begin{abstract}
A phylogenetic analysis of heterotrophic bacterial populations inhabiting streams and groundwater contaminated by acid mine drainage (AMD) was conducted. The samples were collected from sites around an inactive underground Dae-Sung coal mine at Keumsan, Korea. The investigation showed pigment-forming bacteria to be the major strains inhabiting the pollutant, accounting for up to approximately $50 \%$ of all isolates. Twenty-six pigment-forming bacteria were isolated and their taxonomic characteristics determined by phenotypic, chemotaxonomic and phylogenetic analyses. Based on a phylogenetic analysis using 16S ribosomal RNA gene nucleotide sequences, these isolates were found to fall within four major phylogenetic groups: $\alpha, \beta$, and $\gamma$ subdivisions of Proteobacteria; and low-G+C gram-positive bacteria. The $\alpha$-Proteobacteria were further separated into $\alpha-1$, $\alpha-2$ and $\alpha-4$ subclasses. Many isolates from the polluted stream (site P5) and groundwater (site G) were identified as Sphingomonas of the Proteobacteria $\alpha-4$ subclass. Because strains P5-21 and P5-11 appeared to be novel species within the genus Sphingomonas, the discussion was focused on their taxonomy as well as abundance in the polluted regions.
\end{abstract}

Key words: acid mine drainage (AMD), oligotrophs, Proteobacteria $\alpha-4$, Sphingomonas $\mathrm{sp}$

Some natural environments have been made extremely acidic by human activity, particularly mining for coal and metal ores ${ }^{5}$. Acid mine drainage (AMD) has long been recognized to be greatly affected by microbial activity. The dissolution of sulfide ores exposed to oxygen, water, and microorganisms results in the production of acid and environmentally detrimental $\mathrm{AMD}^{11,12)}$.

To date, investigations of microbial populations inhabiting AMD environments have mainly focused on chemolithotrophic bacteria. Two species, Thiobacillus ferrooxidans and Leptospirillum ferrooxidans, which are extensively distributed in acidic drainage, have been recognized as major bacterial species in AMD environments, Recently, several new acidophilic heterotrophic bacteria have been isolated from acid-leaching environments ${ }^{8,23,24,25)}$.

Acidophilic bacteria are known to play an important role

* Corresponding author; E-mail: kswhang@mokwon.ac.kr, Tel: +82-42-829-7593, Fax: +82-42-829-7590 in microbial ecosystems contaminated by AMD but the analysis of microbial populations has been limited to acidic environments. Therefore to extensively investigate microbial populations in AMD contaminated environments, we examined the presence of oligotrophs which can grow on a diluted nutrient broth medium with a neutral $\mathrm{pH}$ among heterotrophs.

The Ok-Chen geosyncline area with about twenty abandoned coal mines is located in the southeastern part of Chung-Nam, Korea. Forest and stream ecosystems at the site have been seriously contaminated by AMD from abandoned coal mines. There has been a report on the geochemical characteristics of water and soil contaminated by AMD originating from abandoned coal mines and coal waste rock in Keumsan near OK-Chen ${ }^{18}$. The report had revealed that the polluted sites not only were acidic with a $\mathrm{pH}$ ranging from 3.4 to 3.8 , but also contained high concentrations of heavy metals such as $\mathrm{As}, \mathrm{Cr}, \mathrm{Ni}, \mathrm{Mo}$ and $\mathrm{Ba}$ ions ${ }^{7}$. 
We carried out an investigation of the microbial population inhabiting groundwater and an acidic stream draining from an abandoned coal mine and coal waste rock in the Chung-Nam region. Twenty-six strains of heterotrophic bacteria were isolated from the polluted sites and their taxonomic characteristics were determined. In this report, we described the phenotypic and chemotaxonomic characteristics and the phylogenetic positions of these isolates.

\section{Materials and Methods}

\section{Site description and sample collection}

Studies were carried out with stream water from an area polluted by AMD from the abandoned coal mine, Keumsan. The $\mathrm{pH}$ of the polluted sites (sites P1-P5) ranged from 3.4 to 3.8. Sulfate concentrations were between 237 and 310 ppm, 10 times higher than those of an unpolluted stream (Sites U1 and U2). Meanwhile the groundwater (site G) in these regions showed $\mathrm{pH}$ values between 5 and 6 . All samples were collected in April 1999. Prior to sample collection, all glassware used was rinsed in deionized water and then autoclaved. Groundwater samples were collected using a impeller pump.

\section{Bacterial counting}

Bacterial numbers were determined by the dilution plate method. One milliliter of an adequate dilution of the sample and sterile distilled water was pipetted into a 100 -fold dilution of nutrient broth (DNB) medium which was composed of $0.01 \%(\mathrm{w} / \mathrm{v})$ beef extract (Difco Laboratories, Detroit, U.S.A.), $0.01 \%$ (w/v) peptone (Kyokuto Seiyaku, Tokyo, Japan), and $0.005 \%(\mathrm{w} / \mathrm{v}) \mathrm{NaCl}$ and was adjusted to $\mathrm{pH} 7.0$ with $1 \mathrm{~N} \mathrm{NaOH.} \mathrm{For} \mathrm{DNB} \mathrm{agar} \mathrm{plates,} 1.2 \%$ (w/v) agar (Wako Pure Chemical Industries, Japan) was added to the medium. Five replicates were prepared in all cases. After incubation for 2 weeks at $25^{\circ} \mathrm{C}$, bacterial colony forming units (CFU) in each water sample were enumerated.

\section{Morphological and cultural characteristics}

Morphological characteristics including cell shape, size, and motility, as well as the cell arrangement of each isolate were examined with a phase contrast microscope (Carl Zeiss Jena GmbH, Bundesrepublik, Germany) $(\times 1000)$. Hucker's modified method was used for Gram-staining ${ }^{17)}$. The catalase test was performed by adding a $3 \%(\mathrm{w} / \mathrm{v})$ hydrogen peroxide solution drop-wise onto cells grown on DNB agar. The cytochrome oxidase test was performed with Kovac's reagent ${ }^{3)}$. The Hydrolysis of starch was determined according to the method of Cowan ${ }^{3)}$. Nitrate reduction was studied as described by Lanyi ${ }^{91}$. Indole production was observed by growing cells in DNB with $0.03 \%$ tryptophan for 3-7 days and then adding Kovac's reagent ${ }^{3)}$. The Oxidation/fermentation test was performed by the method of Lysenko ${ }^{10)}$, using DNB medium supplemented with filter-sterilized $0.2 \%$ glucose.

\section{Determination of chemotaxonomic characteristics}

Freeze-dried cells required for chemotaxonomic analysis were prepared from cultures grown in DNB medium on a rotary shaker at an optimal temperature for each organism. Methyl esters of cellular fatty acid were prepared by the direct transmethylation method with 5\% methanolic hydrochloride ${ }^{19)}$. Each peak was identified by comparing with commercially available standards and by GC-MS (HP

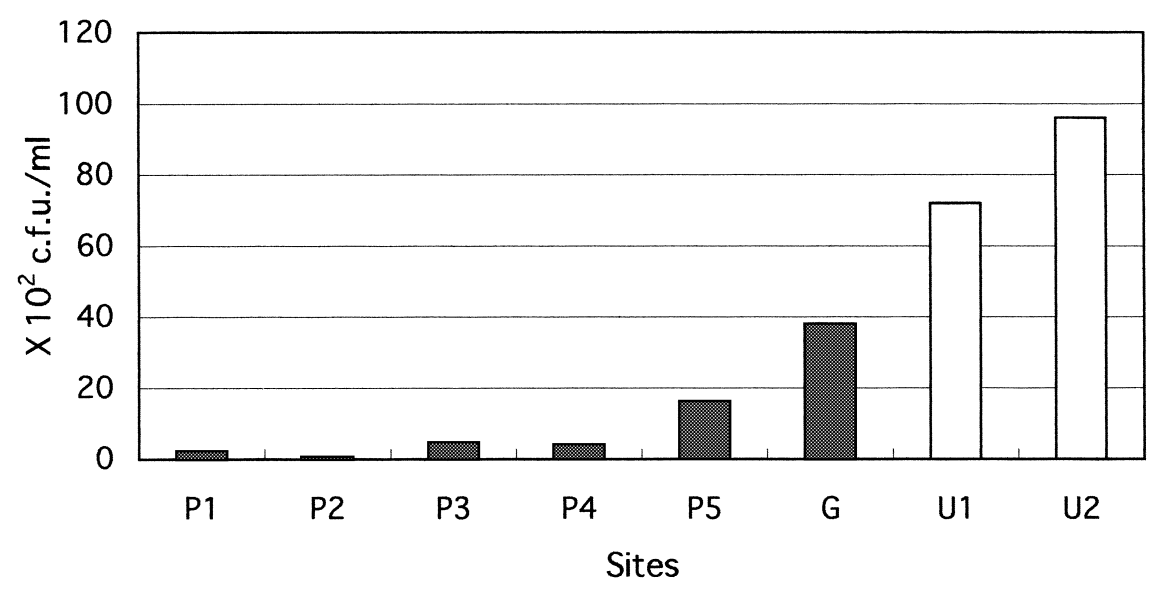

Fig. 1. Bacterial numbers in stream water contaminated with acid mine drainage (P1-P5), groundwater (G), and unpolluted stream water (U1, $\mathrm{U} 2)$. 
5890 series II, Hewlett-Packard Co., Avondale Division, Penn., U.S.A.) equipped with an HP 5971 mass selective detector and an HP5MS column $(30 \mathrm{~m} \times 0.25 \mathrm{~mm}, 0.25 \mu \mathrm{m}$ film thickness; Hewlett Packard). Helium was used as the carrier gas. Injection and detector temperatures were maintained at $250^{\circ} \mathrm{C}$ with an initial column temperature of $120^{\circ} \mathrm{C}$

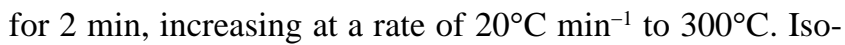
prenoid quinones were extracted according to the method of Collins et al. ${ }^{2)}$ and were analyzed by HPLC with a Cosmosil $5 \mathrm{C}_{18}$ column (4.6×150 mm; Nacalai Tesqu, Tokyo, Japan). The elution solvent was a mixture of methanol and chloroform $(2: 1, \mathrm{v} / \mathrm{v})$.

\section{$16 S$ rDNA sequence analysis}

Genomic DNA was extracted from each strain as previously described $^{1)}$. $16 \mathrm{~S}$ rDNA was amplified by PCR with a
Taq DNA polymerase (Takara) and primers 20F (positions 10-25, Escherichia coli numbering) and $1540 \mathrm{R}$ (positions 1542-1525). Amplification was carried out using a DNA thermal cycler (GeneAmp PCR System 9700; Applied Biosystems) according to the following program: $94^{\circ} \mathrm{C}$ for 1 min followed by 30 cycles of denaturation $\left(94^{\circ} \mathrm{C}\right.$ for 15 sec.), primer annealing $\left(55^{\circ} \mathrm{C}\right.$ for $15 \mathrm{sec}$.) and primer extension $\left(72^{\circ} \mathrm{C}\right.$ for $\left.1.5 \mathrm{~min}\right)$. At the end of the cycle, the reaction mixture was kept at $72^{\circ} \mathrm{C}$ for $10 \mathrm{~min}$ and then cooled to $4^{\circ} \mathrm{C}$. The amplified fragments were purified with a Qiagen PCR Purification Kit (Qiagen Inc.,). The 16S rDNA was sequenced from both directions with an automated fluorescence sequencer model 373A (Applied Biosystems, Foster City, Calif., U.S.A.) with forward and reverse primers a which span $E$. coli $16 \mathrm{~S}$ rDNA positions 785 to 805 and 1115 to 1100 , respectively. The determined sequences were com-

Table 1. Some characteristics of isolates from contaminated by acid mine drainage stream and groundwater.

\begin{tabular}{|c|c|c|c|c|c|c|c|c|c|c|c|}
\hline Isolates & Gram stain & Cell shape & Motility & Pigment & $\begin{array}{l}\text { Fluorescent } \\
\text { pigment }\end{array}$ & $\begin{array}{c}\text { Nitrate } \\
\text { reduction }\end{array}$ & $\begin{array}{l}\text { Hydrolysis } \\
\text { of starch }\end{array}$ & $\begin{array}{l}\text { Indole } \\
\text { production }\end{array}$ & $\begin{array}{l}\text { OF test } \\
\text { (glucose) }\end{array}$ & Oxidase & Catalase \\
\hline U-2 & - & Rods & - & Cream & - & - & - & - & $\mathrm{F}$ & + & - \\
\hline $\mathrm{U}-3$ & - & Rods & + & Cream & - & + & - & - & $\mathrm{F}$ & - & - \\
\hline $\mathrm{U}-4$ & - & Rods & - & Cream & - & + & - & - & NA & + & + \\
\hline G-3 & - & Rods & - & Cream & - & - & - & - & $\mathrm{F}$ & + & - \\
\hline G-4 & - & Rods & + & Cream & - & - & - & - & F & + & - \\
\hline G-12 & - & Rods & - & Yellow & - & - & - & - & $\mathrm{F}$ & + & - \\
\hline G-14 & - & Rods & + & Yellow & - & - & - & - & $\mathrm{F}$ & + & - \\
\hline G-17 & + & Coccus & - & Yellow & - & - & - & - & F & - & + \\
\hline G-21 & - & Rods & - & Pink & - & + & - & - & $\mathrm{F}$ & + & - \\
\hline G-23 & - & Rods & - & Orange & - & - & - & - & $\mathrm{F}$ & + & - \\
\hline G-33 & - & Rods & - & Yellow & - & - & - & - & F & + & - \\
\hline G-36 & + & Coccus & - & Yellow & - & - & - & - & F & - & + \\
\hline G-37 & - & Rods & - & Pink & W & + & - & - & F & $\begin{array}{l}+ \\
-\end{array}$ & + \\
\hline P5-2a & - & Rods & - & Yellow & - & + & - & - & $\mathrm{F}$ & - & - \\
\hline P5-2b & - & Rods & + & Orange & - & - & - & - & $\mathrm{F}$ & - & W \\
\hline P5-5 & - & Rods & - & Orange & - & - & - & - & F & + & - \\
\hline P5-10 & - & Rods & + & Cream & - & + & - & - & $\mathrm{F}$ & + & - \\
\hline P5-11 & - & Rods & - & Orange & - & - & - & - & $\mathrm{F}$ & - & - \\
\hline P5-13 & - & Rods & + & Cream & - & + & - & - & $\mathrm{F}$ & + & - \\
\hline $\mathrm{P} 5-21$ & - & Rods & - & Yellow & - & + & - & - & $\mathrm{F}$ & - & W \\
\hline P5-24 & - & Rods & - & Orange & - & + & - & - & $\mathrm{F}$ & + & - \\
\hline P5-25 & - & Rods & + & Cream & - & + & - & - & $\mathrm{F}$ & + & - \\
\hline P5-29 & - & Rods & - & Orange & - & + & - & - & $\mathrm{F}$ & - & - \\
\hline P5-31 & - & Rods & - & Yellow & - & + & - & - & $\mathrm{F}$ & + & - \\
\hline P5-36 & - & Rods & - & Yellow & - & - & - & - & F & + & - \\
\hline P5-41 & - & Rods & - & Pink & - & - & - & - & $\mathrm{F}$ & + & + \\
\hline
\end{tabular}

+ , positive; w, weakly positive; -, negative 
pared with the DDBJ/EMBL/GenBank DNA databases using the BLAST program and Clustal $\mathrm{W}$ program package ${ }^{22)}$. Phylogenetic trees based on the neighbor-joining method ${ }^{16)}$ were made, and the reliability of tree topologies was estimated by 1000 bootstrap resamplings.

\section{Results and Discussion}

\section{Bacterial numbers}

Bacterial numbers in stream water contaminated by AMD (sites P1-P5), unpolluted stream water (sites U1 and
U2), and groundwater ( site G) are shown in Fig 1. Counts in polluted samples (sites P1-P5) and groundwater (site G) ranged from $0.5 \times 10^{2}$ to $3.8 \times 10^{3} \mathrm{cfu} / \mathrm{ml}$, about $2-100$ fold less than the counts for the unpolluted water (sites U1 and $\mathrm{U} 2$ ), indicating that oligotrophs were distributed in the polluted sites although in smaller numbers than at unpolluted sites.

\section{Phenotypic characteristics}

The isolates on DNB medium appeared to form mucous, convex colonies, the color of which was variable; creamy,

Table 2. Cellular fatty acid composition (\%) and quinone system of isolates.

\begin{tabular}{|c|c|c|c|c|c|c|c|c|c|}
\hline \multirow{2}{*}{ Fatty acid } & \multicolumn{9}{|c|}{ Fatty acid composition (\%) } \\
\hline & P5-24 & P5-29 & P5-31 & G-14 & G-37 & P5-10 & G-4 & P5-13 & G-17 \\
\hline \multicolumn{10}{|l|}{ Saturated } \\
\hline 10:0 & & & & & & 0.34 & 0.53 & 0.37 & \\
\hline $12: 0$ & & & & & & 2 & 5.43 & 4.30 & 0.52 \\
\hline $14: 0$ & 0.47 & 1.20 & & & 3.23 & 0.96 & 0.46 & 0.36 & 7.19 \\
\hline $15: 0$ & 0.35 & 1 & & & 3.83 & 0.52 & 0.34 & & 5.48 \\
\hline $16: 0$ & 8.25 & 11.66 & 9.21 & 5.91 & 21.7 & 30.24 & 30.63 & 15.76 & 35.88 \\
\hline 17:0 & 0.14 & & & & 1.61 & 0.25 & 0.15 & 0.4 & 3.13 \\
\hline 18:0 & 0.58 & 1.53 & 0.77 & 1.2 & 0.40 & 0.79 & 0.24 & 1.69 & 0.88 \\
\hline \multicolumn{10}{|l|}{ Unsaturated } \\
\hline $16: 1$ & 1.54 & & & 1.09 & & & 0.15 & & \\
\hline $17: 1$ & 2.15 & 2.60 & 1.01 & & 2.74 & & & & 1.3 \\
\hline $18: 1$ & 55.25 & 53.58 & 66.23 & 62.07 & 58.63 & 5.68 & 8.06 & 28.79 & 22 \\
\hline \multicolumn{10}{|l|}{ Methyl-branched } \\
\hline $19: 0$ iso & & & & & & 0.73 & & 2.25 & \\
\hline 15:0 anteiso & & 6.83 & & & & & & & \\
\hline 17:0 anteiso & & 3.44 & & & & & & & \\
\hline 19:0 anteiso & & 1.18 & & & & & & & \\
\hline \multicolumn{10}{|l|}{ Hydroxy } \\
\hline $10: 03 \mathrm{OH}$ & & & & & & 2.52 & 5.52 & 0.96 & \\
\hline $12: 02 \mathrm{OH}$ & 0.11 & 1.28 & & & & 8.15 & 1.77 & 2.94 & \\
\hline $12: 03 \mathrm{OH}$ & & & & & 2.96 & 6.98 & & 4.59 & \\
\hline $14: 02 \mathrm{OH}$ & 13.56 & 12.92 & 19.9 & 20.27 & & & & & \\
\hline $15: 02 \mathrm{OH}$ & 0.38 & & 0.59 & & & & & & \\
\hline $16: 02 \mathrm{OH}$ & 0.19 & & 0.39 & & & & & & \\
\hline $16: 12 \mathrm{OH}$ & 0.17 & 0.78 & & & & & & & \\
\hline $18: 12 \mathrm{OH}$ & 3.49 & & 0.52 & 3.43 & & & & & \\
\hline \multicolumn{10}{|l|}{ Cyclopropane } \\
\hline 17:0 cyclopropane & & & 10.55 & 0.95 & & 21.56 & 23.73 & & \\
\hline 19:0 cyclopropane & & & & & & 5.59 & & & \\
\hline \multicolumn{10}{|l|}{ Others } \\
\hline Sumed feature 3 & 13.08 & 1.98 & 0.89 & 5.08 & 4.68 & 13.32 & 22.99 & 26.81 & 16.4 \\
\hline Sumed feature 6 & & & & & & & & & 4.64 \\
\hline Quinone system & Q-10 & Q-10 & Q-10 & Q-10 & Q-10 & Q-9 & Q-8 & Q-8 & MK-7 \\
\hline
\end{tabular}




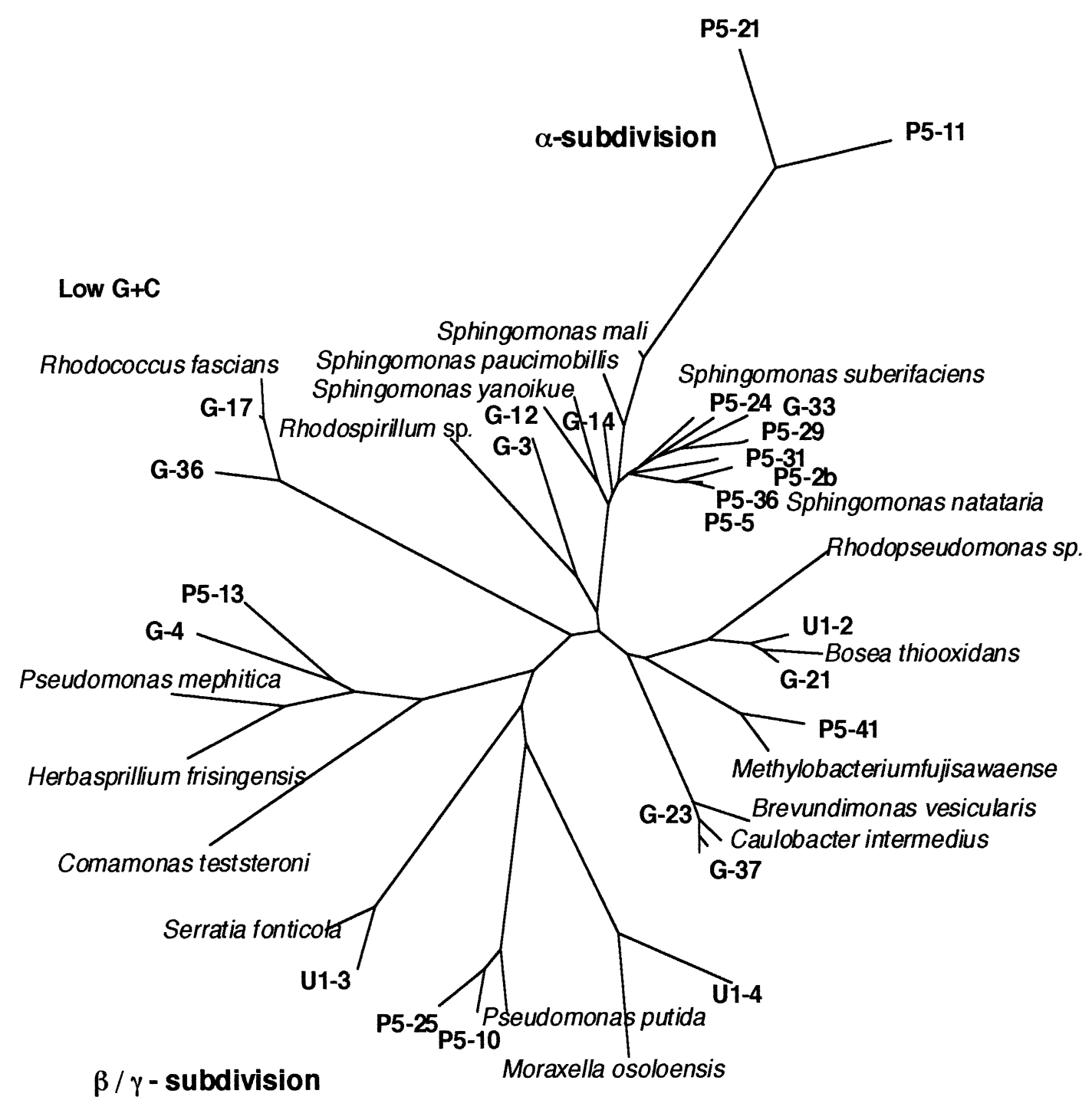

0.1

Fig. 2. Distance tree for the known Proteobacteria, low G+C gram-positive bacteria, and strains from a contaminated stream (P5) and groundwater $(\mathrm{G})$.

yellow, orange, and pale pinkish, when grown at $28^{\circ} \mathrm{C}$. Of a total of 341 isolates, 168 were classified as pigment-forming bacteria and 26 of these were selected and partially characterized (see Table 1).

Most of the selected strains were aerobic, gram-negative rod-shaped organisms whose cells were 0.5 by $1.5 \mu \mathrm{m}$. Only two strains, G-17 and G-36, were gram-positive cocci. Some strains were catalase-positive, oxidase-negative.

\section{Quinone and cellular fatty acid compositions}

Nine representative strains were analyzed as to their cellular fatty acids (Table 2). Most strains contained mainly 16-carbon (16:0), unsaturated 18-carbon (18:1) and 18-carbon (18:0) fatty acids. Strains were classified based on the presence of 2- or 3-hydroxy acids, although these fatty acids usually accounted for less than $10 \%$ of the total ${ }^{13)}$. Some strains (P5-24, P5-29, P5-31, G-14) contained a significant amount of 2-OH 14:0. The major isoprenoid quinone of 


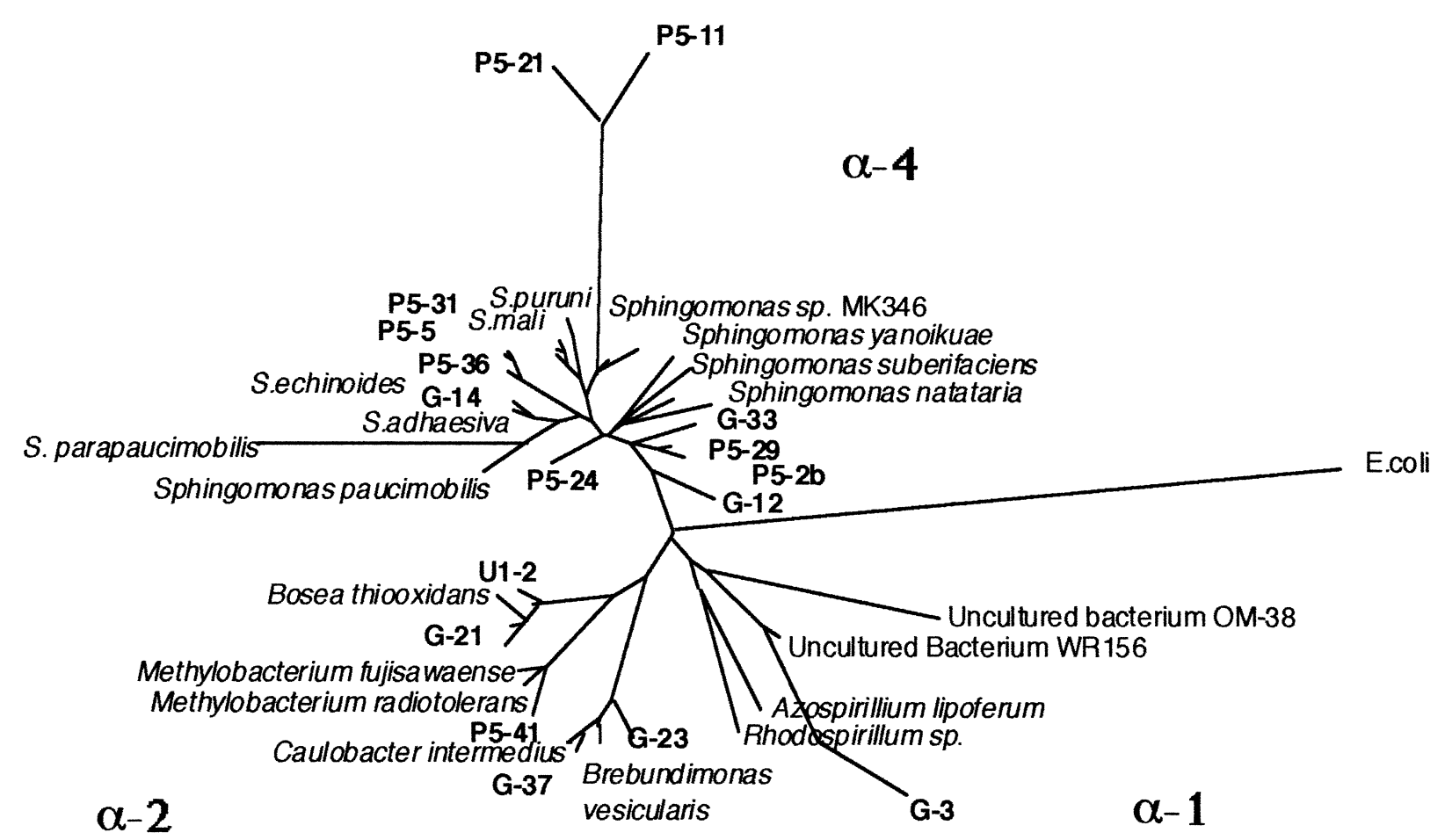

0.1

Fig. 3. Phylogenetic tree including strains of a contaminated stream (P5) and groundwater (G) belonging to the $\alpha$-subdivision of Proteobacteria.

these isolates was ubiquinone with 10 isopren units (Q-10). Chemotaxonomic data indicated these isolates show some resemblance to the genus Sphingomonas: the presence of 18:1, 2-OH 14:0, 2-OH 15:0 and 2-OH 16:0 as the major cellular fatty acids.

\section{Phylogenetic characteristics}

Phylogenetic analysis revealed the twenty-six strains to fall within four major phylogenetic groups: low $\mathrm{G}+\mathrm{C}$ grampositive bacteria (2 strains); Proteobacteria $\alpha$-subdivision (17 strains); $\beta$-subdivision (2 strains), and $\gamma$-subdivision (4 strains) (Fig. 2). According to the phylogenetic trees, ten strains were closely related (95\% similarity) to known species. The other strains were less closely related to known species, with sequence similarity values ranging from 87 to $94 \%$.

The $\alpha-4$ subclass of Proteobacteria from contaminated stream and groundwater

Takeuchi et al. suggested that the $\alpha$-subdivision of Proteobacteria can be divided into several subgroups ${ }^{21)}$.
Our new isolates of the $\alpha$-subdivision were therefore further separated into three subclasses: $\alpha-1, \alpha-2$ and $\alpha-4$ (Fig. 3). Eleven isolates (P5-21, P5-11, P5-24, P5-29, P5-31, P5-2b, P5-36, P5-5, G-12, G-14 and G-33) belonging to the Proteobacteria $\alpha-4$ subclass were placed in the clusters of Sphingomonas. Many isolates from polluted stream water (site P5) and groundwater (site G) were identified as Sphingomonas of the Proteobacteria $\alpha-4$ subclass.

The genus Sphingomonas can be described as follows ${ }^{26)}$. The cells are gram-negative, nonspore-forming, straight rods. Colonies are deep-yellow or whitish brown. Catalase activity is present and the bacteria are obligately aerobic. The respiratory quinone is ubiquinone 10 and the major cellular fatty acids are 18:1 and/or 17:1, as well as one or more of 2-OH 14:0, 2-OH 15:0, and 2-OH 16:0. There is an absence of 3-hydroxy fatty acids. Both the phenotypic, chemotaxonomic and phylogenetic characteristics indicate that our isolates of $\alpha-4$ Proteobacteria are closely related to the genus Sphingomonas.

According to the phylogenetic tree shown in Fig. 4, the clade consisting of new isolates (P5-11 and P5-21) is very 


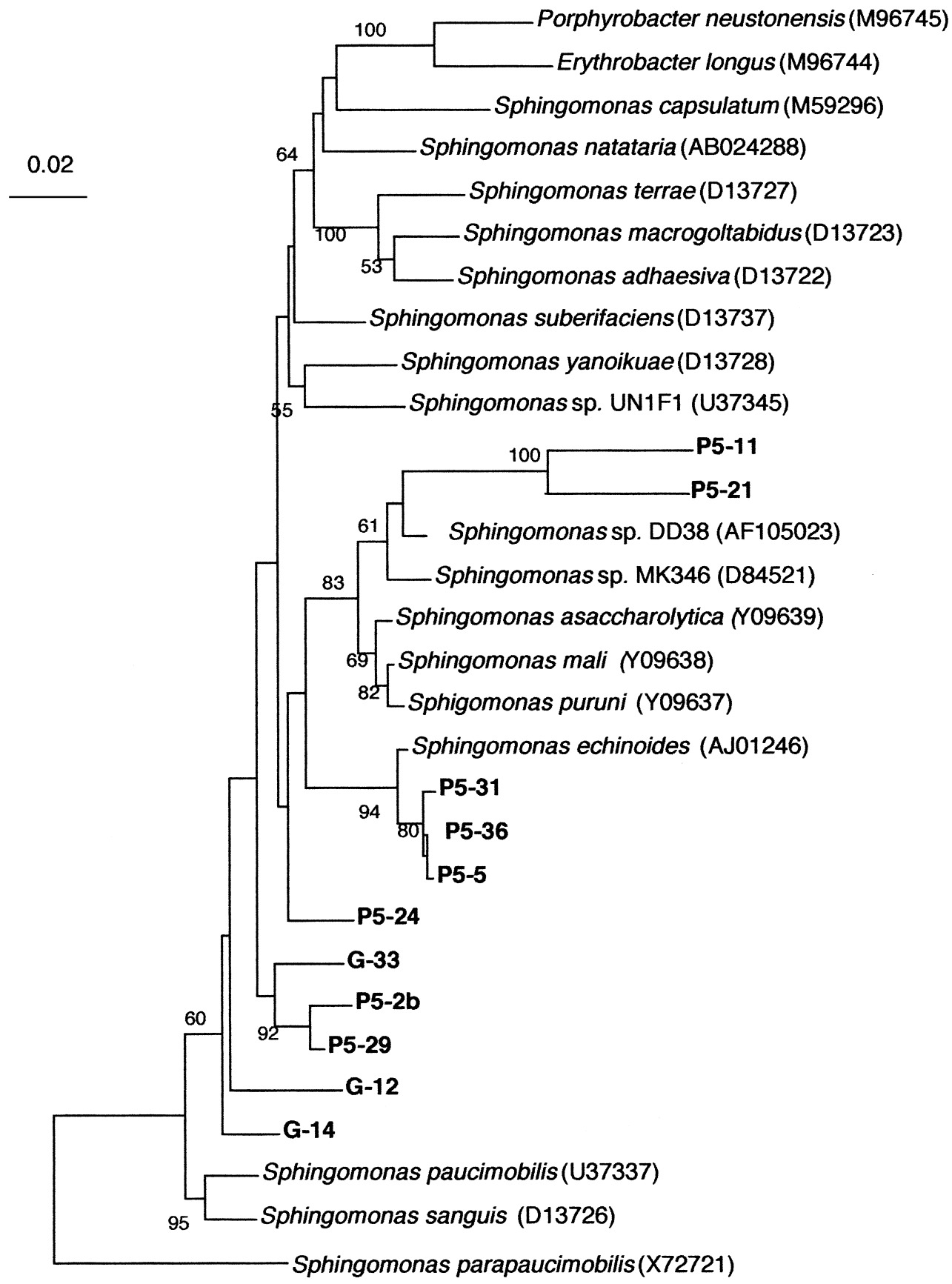

Fig. 4. Phylogenetic tree of strains belonging to the genus Sphingomonas. The numbers on the branches indicate the bootstrap value of 1000 replicates (greater than 50\%). The numbers in parentheses are the GenBank/EMBL/DDBJ database accession numbers.

likely to represent new species of the genus Sphingomonas, though more taxonomic data will be needed to confirm the phylogenetic result. However, six strains (P5-24, G-33, P5-2b, P5-29, G12 and G14) were distant from the core Sphingomonas species.

The sphingan-secreting bacteria, genus Sphingomonas, were isolated from a number of environments such as soil and water samples, and human clinical specimens ${ }^{4,14)}$. Although the roles of Sphingomonas are not yet well established, there are reports that the bacteria have the ability to degrade lignin ${ }^{6,20)}$ and are involved in the pathogenesis of S. paucimobilis ${ }^{15)}$.

Thiobacillus ferroxidans and Leptospirillum ferroxidans have been reported as the predominant species inhabiting 
streams polluted with acid. However it is worth noting that bacteria such as Sphingomonas were detected in a similar environment, using DNB medium for oligotrophs. In fact, chemolithotrophic bacteria such as $T$. ferroxidans and $L$. ferroxidans might play important roles in polluted water as representative microorganisms. However, the evaluation of water quality based only on representative bacteria can give unreliable results. Further investigation of the microbial populations and species in the AMD environment is needed.

\section{Acknowledgments}

The Authors gratefully thank Prof. M. Kim, Prof. E. Min and Prof. S. Song, the Faculty of Life Resource of Joong-Bu University, for their help in collecting water samples and helpful comments.

\section{References}

1) Ausubel, F.M., R. Brent, R.E. Kingston, D.D. More, J.G. Seidman, J.A. Smith and K. Struhl. 1987. Current Protocols in Molecular Biology. John Wiley and Sons, Chichester, pp. 2.4.12.4.5.

2) Collins, M.D., T. Pirouz, M. Goodfellow and D.E. Minnikin. 1977. Distribution of menaquinones in actinomycetes and corynebacteria. J. Gen. Microbiol. 100: 221-230.

3) Cowan, S.T. 1974. Manual for the identification of medical bacteria, 2nd ed., Cambridge University Press, Cambridge, U.K.

4) Holmes, B., R.J. Owen, A. evans, H. Malnick and W.R. Willcox. 1977. Pseudomonas paucimobilis, a new species isolated from human clinical specimens, the hospital environment, and other sources. Int J. Syst. Bacteriol. 27: 133-146.

5) Johnson, D.B. 1995. Selective solid media for isolating and enumerating acidophilic bacteria. J. Microbial Methods. 23: 205218.

6) Katayama, Y., S. Nishikawa, A. Murayama, M. Yamasaki, N. Morohoshi and T. Haraguchi. 1988. The metabolism of biphenyl structures in lignin by the soil bacterium (Pseudomonas paucimobilis SYK-6). FEMS Letters 233: 129-133.

7) Kim, M., E. Min and S. Song. 1997. Effect of contamination by the abandoned coal mine drainage on the stream water in Keumsan, Chungnam. J. Kor. Fore. Soc. 86: 435-442.

8) Kishimoto, N. and T. Tano. 1987. Acidophilic heterotrophic bacteria isolated from acidic mine drainage, sewage, and soil. J. Ge. Appl. Microbiol. 33: 11-25.

9) Lanyi, B. 1987. Classical and rapid identification methods for medically important bacteria. Methods Microbiol. 19: 161-203.

10) Lysenko, O. 1961. Pseudomonas-An attempt at a general classification. J. Gen. Microbiol. 25: 379-408.

11) Nordstrom, D.K. and G. Southam. 1997. Geomicrobiology of sulfide mineral oxidation, p. 361-390. In J.F. Banfield and K.H. Nealson (ed.), Geomicrobiology: interactions between microbes and minerals, Vol. 35. Mineralogical Society of America, Washington, D.C.
12) Nordstrom, D.K. and C.N. Alpers. 1999. Negative pH, efflorescent mineralogy, and consequences for environmental restoration at the Iron Mountain Superfund site, California. Proc. Natl. Acad. Sci. Usa. 96: 3455-3462.

13) Oyaizu, H. and K. Komagata. 1983. Grouping of Pseudomonas species on the basis of cellular fatty acid composition and the quinone system with special reference to the existence of 3hydroxy fatty acids. J. Gen. Appl. Microbiol. 29: 17-40.

14) Pollock, T.J. 1993. Gellan-related polysaccharides and the genus Sphingomonas. J. Gen. Microbiol. 139: 1939-1945.

15) Reina, J., A. Bassa, I. Llompart, D. Portela and N. Borrell. 1991. Infections with Pseudomonas paucimobilis: report of four cases and review. Reviews of Infections Diseases 13: 1072-1076.

16) Saito, N. and M. Nei. 1987. The neighbor-joining method: a new method for reconstructing phylogenetic trees. Mol. Biol. Evol. 4: 406-425.

17) Skerman, V.B.D. 1967. A guide to the identification of the genera of bacteria, 2nd ed., Williams and Wilkins Books Co., Baltimore.

18) Song, S., E. Min and M. Kim. 1997. Pollution by acid mine drainages from the Daeseong coal mine in Keumsan. Econ. Environ. Geol. 30: 105-116.

19) Suzuki, K. and K. Komagata. 1993. Taxonomic significance of cellular fatty acid composition in some Coryneform Bacteria. Int. J. Syst. Bacteriol. 33: 188-200.

20) Taira, K., N. Hayase, N. Arimura, S. Yamashita, T. Miyazaki and K. Furukawa. 1988. Cloning and nucleotide sequence of the 2,3dihydroxybiphenyl dioxygenase gene from the PCB-degrading strain of Pseudomonas paucimobilis Q1. Biochemistry 27: 39903996.

21) Takeuchi, M., H. Sawada, H. Oyaizu and A. Yokoda. 1994. Phylogenetic evidence for Sphingomonas and Rhizomonas as nonphytosynthetic members of the alpha-4 subclass of the Proteobacteria. Int. J. Syst. Bacteriol. 44: 308-314.

22) Thompson, J.D., D.G. Higgins and T.J. Gibson. 1994. CLUSTAL $\mathrm{W}$ : improving the sensitivity of progressive multiple sequence alignment through sequence weighting, positions-specific gap pentalties and weight matrix choice. Nucleic. Acids Res. 22: $4673-4680$.

23) Urakami, T. and K. Komagata. 1987. Cellular fatty acid composition with special reference to the existence of hydroxy fatty acids in gram-negative methanol-, methane-, and methylamine-utilizing bacteria. J. Gen. Appl. Microbiol. 33: 135-165.

24) Urakami, T., J. Tamaoka, K. Suzuki and K. Komagata. 1989. Acidomonas gen. nov., Incorporating Acetobacter methanolicus as Acidomonas methanolica comb. nov. Int. J. Syst. Bacteriol. 39: $50-55$.

25) Wakao, N., N. Nagasawa, T. Matsuura, H. Matsukura, T. Matsumoto, A. Hiraishi, Y. Sakurai and H. Shiota. 1994. Acidophilum multivorum sp. nov., an acidophilic chemoorganotrophic bacterium from pyritic acid mine drainage. J. Gen. Appl. Microbiol. 40: 143-159.

26) Yabuuchi, E., I. Yano, H. Oyaizu, Y. Hashimoto, T. Ezaki and H. Yamamoto. 1990. Proposals of Sphingomonas paucimobilis gen. nov. and comb. nov., Sphingomonas parapaucimobilis sp. nov., Sphingomonas yanoikuyae sp. nov., Sphingomonas adhaesiva sp. nov., Sphingomonas capsulata comb. nov., and two genospecies of the genus Sphingomonas. Microbiology and Immunology 34: 99-119. 